\title{
UV effects on photosynthesis and DNA in propagules of three Antarctic seaweeds (Adenocystis utricularis, Monostroma hariotii and Porphyra endiviifolium)
}

\author{
Katharina Zacher • Michael Y. Roleda • Dieter Hanelt • \\ Christian Wiencke
}

Received: 7 September 2006 / Accepted: 24 October 2006 / Published online: 14 December 2006

(C) Springer-Verlag 2006

\begin{abstract}
Ozone depletion is highest during spring and summer in Antarctica, coinciding with the seasonal reproduction of most macroalgae. Propagules are the life-stage of an alga most susceptible to environmental perturbations therefore, reproductive cells of three intertidal macroalgal species Adenocystis utricularis (Bory) Skottsberg, Monostroma hariotii Gain, and Porphyra endiviifolium (A and E Gepp) Chamberlain were exposed to photosynthetically active radiation (PAR), $\mathrm{PAR}+\mathrm{UV}-\mathrm{A}$ and $\mathrm{PAR}+\mathrm{UV}-\mathrm{A}+\mathrm{UV}-\mathrm{B}$ radiation in the laboratory. During $1,2,4$, and $8 \mathrm{~h}$ of exposure and after $48 \mathrm{~h}$ of recovery, photosynthetic efficiency, and DNA damage were determined. Saturation irradiance of freshly released propagules varied between 33 and $83 \mu \mathrm{mol}$ photons $\mathrm{m}^{-2} \mathrm{~s}^{-1}$ with lowest values in $P$. endiviifolium and highest values in $M$. hariotii. Exposure to
\end{abstract}

K. Zacher $(\bowtie)$

Alfred Wegener Institute for Polar and Marine Research, Am Handelshafen 12, 27570 Bremerhaven, Germany

e-mail:kzacher@awi-bremerhaven.de

M. Y. Roleda

Alfred Wegener Institute for Polar and Marine Research,

Biologische Anstalt Helgoland, 27498 Helgoland, Germany

D. Hanelt

Biozentrum Klein Flottbek, University of Hamburg,

Ohnhorst-Str. 18, 22609 Hamburg, Germany

C. Wiencke

Alfred Wegener Institute for Polar and Marine Research,

Am Handelshafen 12, 27570 Bremerhaven, Germany

Present Address:

M. Y. Roleda

Institut für Polarökologie, Wischhofstr. 1-3,

Gebäude 12, 24148 Kiel, Germany
$22 \mu \mathrm{mol}$ photons $\mathrm{m}^{-2} \mathrm{~s}^{-1}$ PAR significantly reduced photosynthetic efficiency in $P$. endiviifolium and $M$. hariotii, but not in $A$. utricularis. UV radiation (UVR) further decreased the photosynthetic efficiency in all species but all propagules recovered completely after $48 \mathrm{~h}$. DNA damage was minimal or not existing. Repeated exposure of $A$. utricularis spores to $4 \mathrm{~h}$ of UVR daily did not show any acclimation of photosynthesis to UVR but fully recovered after $20 \mathrm{~h}$. UVR effects on photosynthesis are shown to be species-specific. Among the tested species, A. utricularis propagules were the most light adapted. Propagules obviously possess good repair and protective mechanisms. Our study indicates that the applied UV dose has no long-lasting negative effects on the propagules, a precondition for the ecological success of macroalgal species in the intertidal.

Keywords Antarctica DNA damage -

Photosynthetic efficiency $\cdot P-I$ curve .

Propagules $\cdot$ UV radiation

$\begin{array}{ll}\text { Abbreviations } \\ \text { PAR } & \text { Photosynthetically active radiation } \\ \text { UV-A } & \text { Ultraviolet-A } \\ \text { UV-B } & \text { Ultraviolet-B } \\ \text { UVR } & \text { UV radiation } \\ \text { P } & \text { PAR } \\ \text { PA } & \text { PAR + UV-A } \\ \text { PAB } & \text { PAR + UV-A + UV-B } \\ \text { CPDs } & \text { Cyclobutane pyrimidine dimers } \\ F_{\mathrm{v}} / F_{\mathrm{m}} & \text { Optimum quantum yield } \\ \mathrm{I}_{\mathrm{k}} & \text { Saturation irradiance } \\ \text { PFD } & \text { Photon flux density } \\ P-I \text { curves } & \text { Photosynthesis irradiance curves } \\ \text { rETR } & \text { Relative electron transport rate }\end{array}$




\section{Introduction}

Seaweeds are the most important primary producers in coastal waters contributing 3.2\% to the global aquatic primary production (Mann 1973). In contrast to pelagic primary producers, macroalgae have complex life cycles including unicellular reproductive cells and microbenthic stages, apart from the macrobenthic thallus. Especially the early developmental stages are highly susceptible to a variety of stresses (Coelho et al. 2000). Therefore, the survival of the early phases of marine macroalgae is critical to the successful establishment of benthic populations (Vadas Sr et al. 1992).

Propagules can be exposed to high photosynthetically active radiation (PAR $=400-700 \mathrm{~nm})$ and ultraviolet radiation (UVR $=280-400 \mathrm{~nm}$ ) after release during their planktonic phase. For example kelp spores can be transported at least several kilometers in the water column and thereby be especially exposed to UVR because no protective shading by canopy algae occurs (Reed et al. 1988). The negative effects to UV exposure on cellular level include, e.g., photoinhibition and/or photodamage (Hanelt et al. 1997), protein breakdown (Lao and Glazer 1996), the production of reactive oxygen species (Rijstenbil et al. 2000) as well as damage to the DNA (van de Poll et al. 2001, 2002) and other biomolecules through the direct absorption of UVR (Vass 1997). These impacts can result in low growth rates (Roleda et al. 2006b). Moreover diversity and species richness of algal communities can be negatively affected due to UVR (K. Zacher unpublished data; Dobretsov et al. 2005).

UVR effects on macroalgae are species-specific. Different acclimation and repair mechanisms exist in species most tolerant to UV stress coming from shallow waters (Larkum and Wood 1993). Photosynthesis is a dynamic process and excessively absorbed energy, which is not utilized in photochemistry, can be converted into harmless thermal radiation until a certain point (Hanelt 1996). Maximum quantum yield of photosynthesis of, e.g., the intertidal brown alga Alaria esculenta can acclimate to enhanced levels of UVR within a few days (Bischof et al. 1999). Recovery after photodamage of the D1 protein of photosystem II is reflected by the new synthesis of this protein (Bischof et al. 1998). Other strategies can be avoidance of UVR or the production of screening compounds (reviewed in Franklin and Forster 1997; Bischof et al. 2006). Furthermore, DNA damage can be repaired enzymatically by light-dependent photolyases and light-independent nucleotide excision (van de Poll et al. 2002).

Although the unicellular propagules are clearly the stages most susceptible to UVR (Wiencke et al. 2006b) most UV studies have been carried out on the adult macrothalli. Some studies exist on the UV impact on spores of Arctic and temperate Laminariales and Gigartinales, showing that their sensitivity is related to their depth distribution and, hence influencing recruitment of the species in the eulittoral zone (Roleda et al. 2004b; Wiencke et al. 2006b). Antarctic intertidal algae are particularly suffering from elevated UV-B radiation $(280-315 \mathrm{~nm})$ during the last two decades due to stratospheric ozone depletion ( $>50 \%$ over this area; WMO 2003). UV-B and UV-A radiation (315-400 $\mathrm{nm}$ ) can reach intensities of more than two and $40 \mathrm{~W} \mathrm{~m}^{-2}$ in spring in the studied area (King George Island, Antarctica), respectively. Furthermore, $1 \%$ of the surface irradiance of UV-B radiation can still be measured in a depth of about $15 \mathrm{~m}$ at clear water conditions. However, UV experiments with Antarctic macroalgae are scarce. To our knowledge these experiments are the first testing the UV sensitivity of reproductive cells from Antarctic field material.

In laboratory experiments propagules of three intertidal Antarctic macroalgal species were exposed to different light treatments to measure photosynthetic performance and DNA damage. The ability of these early developmental stages to recover from UV induced damage was also studied. The study gives valuable insights in the ecological success of Antarctic intertidal algae growing under a highly variable light regime including high UV values during spring and summer. It is hypothesized that propagules from Antarctic intertidal macroalgae can better cope with high UV levels in comparison with algae from Arctic or temperate regions.

\section{Materials and methods}

\section{Algal material}

Fertile specimen of the brown alga Adenocystis utricularis (Bory) Skottsberg, the green alga Monostroma hariotii Gain and the red alga Porphyra endiviifolium (A and E Gepp) Chamberlain were collected between January and March 2005 at Peñon Uno (Dallmann Laboratory, King George Island, South Shetland Islands, $\left.62^{\circ} 14.80^{\prime} \mathrm{S}, 58^{\circ} 41.26^{\prime} \mathrm{W}\right)$. A. utricularis and $M$. hariotii were collected from the eulittoral were they occur together, whereas $P$. endiviifolium grows on rocks in the upper eulittoral. After collection the specimen were brought immediately to the nearby laboratory and put into filtered seawater $\left(2^{\circ} \mathrm{C}\right.$ under low light conditions) until further processing. 
Spore release

Numerous individuals of each species were cleaned with tissue paper, divided randomly in five replicates and prepared for spore release in a temperature controlled room $\left(2 \pm 1.5^{\circ} \mathrm{C}\right)$. P. endiviifolium was put into Petri dishes with seawater for collection of monospores from the asexual thallus. Individuals of $A$. utricularis and $M$. hariotii were put in a wet chamber and left overnight under dim light. Propagules release was obtained by flooding the algae with filtered seawater in Petri dishes. Spore suspension was adjusted for $A$. utricularis spores (zoospore length around $4 \mu \mathrm{m}$ ) to $\sim 7.1 \times 10^{4}$, for $M$. hariotii gametes (length around $7 \mu \mathrm{m})$ to $\sim 1.57 \times 10^{4}$ spores $\mathrm{ml}^{-1}$ and for P. endiviifolium monospores (mean diameter $15 \mu \mathrm{m} \pm 2$. $4 \mathrm{SD}$, $n=32$ ) to $\sim 1.12 \times 10^{4}$ spores $\mathrm{ml}^{-1}$ after counting (Sedgewick-Rafter Cell S50 spore counter, Graticules Ltd., Tonbridge, UK) to obtain the desired background fluorescence for photosynthetic measurements.

\section{Experimental treatments}

Light was provided by white fluorescent lamps (Osram GmbH, L65 Watt/25S, Munich, Germany), emitting background PAR of $400-700 \mathrm{~nm}$ and UV lamps (QPanel UV-A-340, $40 \mathrm{~W}$, Cleveland, USA), emitting a spectrum qualitatively similar to solar radiation in the range of $295-340 \mathrm{~nm}$. Three kinds of filter foils were used to cut off different wavelength ranges from the spectrum emitted by the fluorescent lamps: (1) Ultraphan transparent (Digefra GmbH, Munich, Germany), (2) Folanorm 320 (Folex GmbH, Cologne, Germany), and (3) Ultraphan URUV farblos (Digefra), corresponding to the PAR + UV-A + UV-B (PAB, 280$700 \mathrm{~nm}), \mathrm{PAR}+\mathrm{UV}-\mathrm{A}(\mathrm{PA}, 320-700 \mathrm{~nm})$ and PAR (P, 400-700 nm) treatments, respectively. The available filters cut off wavelengths were slightly differing from the definition of CIE (Commission Internationale De l'Éclairage, UV-B = 280-315 nm, UV-A = 315-400nm).

\section{Irradiance measurements}

Irradiation in the laboratory was measured below the cut-off filters using a Solar Light PMA 2100 radiometer (Solar Light, Philadelphia, PA, USA) equipped with a UV-A (PMA 2110) and a UV-B broad-band sensor (PMA 2106; Solar light). As the spectral range of the UV-A sensor extends into the UV-B region of the spectrum, UV-A radiation measurements were always made using a Schott WG320 filter (Schott, Mainz, Germany) to exclude wavelengths below $320 \mathrm{~nm}$. The UV-B measurements recorded were obtained by subtracting the reading with the WG320 filter from the reading without the filter. PAR was measured using a flat-head LICOR 190 SA quantum sensor (cosine corrected) connected to a LICOR LI-1400 datalogger (LI-COR Bioscience, Lincoln, NE, USA). Irradiance under the different treatments is shown in Table 1. Furthermore, ambient UV-A and UV-B radiation in the air was measured permanently with a 32-channel single-photon counting spectroradiometer (Isitec, Bremerhaven, Germany; Hanken and Tüg 2002) at the Dallmann Laboratory.

\section{Spore photosynthesis}

Photosynthetic efficiency of reproductive cells measured as variable fluorescence of photosystem II (PSII), was determined using a Water Pulse Amplitude Modulation fluorometer (Water-PAM) connected to a PC with WinControl software (Heinz Walz $\mathrm{GmbH}$, Effeltrich, Germany). Immediately after adjustment of cell density (not exceeding $1 \mathrm{~h}$ after spore release), spore suspension was filled into $5 \mathrm{ml}$ Quartz cuvettes. Optimum quantum yield $\left(F_{\mathrm{v}} / F_{\mathrm{m}}\right)$ was measured after 3 min dark adaptation to determine initial photosynthetic efficiency at time zero $(n=5)$ as described by Roleda (2006a), designated as control. After that, the controls were maintained under dim white light $\left(4 \mu \mathrm{mol}\right.$ photons $\left.\mathrm{m}^{-2} \mathrm{~s}^{-1}\right)$ for 2 days before the final measurement. Photosynthesis (in terms of relative electron transport rate, $\mathrm{rETR}=\mathrm{PFR} \times \Delta F /$ $F_{\mathrm{m}}$ ) versus irradiance curves $(P-I$ curves $)$ were also measured in the time zero control $(n=3$, chosen at random from the five replicates) as described by Bischof et al. (1998). The hyperbolic tangent model of Jassby and Platt (1976) was used to estimate $P-I$ curve parameters described as: $\mathrm{rETR}=\mathrm{rETR}_{\max } \times \tanh$ $\left(\alpha \times I_{\mathrm{PAR}} \times \mathrm{rETR}_{\max }^{-1}\right)$, where $\mathrm{rETR}_{\max }$ is the maximum relative electron transport rate, tanh is the hyperbolic tangent function, $\alpha$ is the initial slope in the light limited part of the $P-I$ curve (as a measure for the electron transport efficiency) and $I$ is the photon fluence rate of PAR. The saturation irradiance for

Table 1 Irradiance under the different experimental treatments

\begin{tabular}{llll}
\hline Treatments & $\begin{array}{l}\text { PAR } \\
\left(\mathrm{W} \mathrm{m}^{-2}\right)\end{array}$ & $\begin{array}{l}\mathrm{UV}-\mathrm{A} \\
\left(\mathrm{W} \mathrm{m}^{-2}\right)\end{array}$ & $\begin{array}{l}\mathrm{UV}-\mathrm{B} \\
\left(\mathrm{W} \mathrm{m}^{-2}\right)\end{array}$ \\
\hline PAB (PAR + UV-A + & 4.73 & 4.34 & 0.35 \\
UV-B) & & & \\
PA (PAR + UV-A) & 4.73 & 4.05 & 0.07 \\
P (PAR) & 4.73 & 0.06 & 0.00 \\
\hline
\end{tabular}

Under the recovery shelf PAR irradiance was $0.86 \mathrm{~W} \mathrm{~m}^{-2}$ $\left(4 \mu \mathrm{mol} \mathrm{m}{ }^{-2} \mathrm{~s}^{-1}\right)$ 
electron transport $\left(I_{k}\right)$ was calculated as the intercept between $\alpha$ and the $\mathrm{rETR}_{\max }$ values. Curve fit was calculated with the Solver module of MS-Excel using the least square method comparing differences between measured and calculated data.

To evaluate the effect of different radiation and exposure time treatments, $5 \mathrm{ml}$ spore suspension were filled into $35 \times 10 \mathrm{~mm}$ cell culture dish $(n=5)$ and exposed to the three radiation conditions for $1,2,4$, and $8 \mathrm{~h}$ at $2 \pm 1.5^{\circ} \mathrm{C}$. Spores from A. utricularis were exposed in another experiment for 2, 8, and $16 \mathrm{~h}$ (Table 2). After $F_{\mathrm{v}} / F_{\mathrm{m}}$ measurements, the spore suspension was returned to their respective culture dishes and allowed to recover for 2 days under dim white light $\left(4 \mu \mathrm{mol}\right.$ photons $\left.\mathrm{m}^{-2} \mathrm{~s}^{-1}\right)$ condition. Furthermore, a time series experiment was performed exposing $A$. utricularis spores repeatedly to $\mathrm{PAB}, \mathrm{PA}$ and $\mathrm{P}$ for $4 \mathrm{~h}$ daily followed by $20 \mathrm{~h}$ under $\operatorname{dim}$ white light ( $4 \mu \mathrm{mol}$ photons $\mathrm{m}^{-2} \mathrm{~s}^{-1}$ ) over a period of 5 days. Photosynthetic efficiency was measured directly after the treatment and after recovery (Table 2).

Spore DNA damage and repair

DNA damage and subsequent repair of this damage was determined after 1,2, 4, and $8 \mathrm{~h}$ exposure to UV-B radiation. From the working spore suspension, $40 \mathrm{ml}$ was used for each experimental unit. For each treatment, six experimental units were prepared. After the irradiation treatment, three experimental units (as replicates) were processed immediately while the other three were allowed to recover for 2 days in low white light before processing. The spore samples were filtered through $44 \mathrm{~mm}$ diameter $1.0-2.0 \mu \mathrm{m}$ pore size Nuclepore ${ }^{\circledR}$ polycarbonate membrane filters (Whatman, London, UK) and frozen at $-80^{\circ} \mathrm{C}$ in $2-\mathrm{ml}$ Eppendorf tubes for further DNA extraction and analysis of cyclobutane pyrimidine dimers (CPDs).

DNA was extracted using CTAB and quantified as described by Roleda et al. (2004b). The accumulation of CPDs was determined following a two step antibody assay using anti-thymine dimer H3 (Affitech, Oslo, Norway) and rabbit anti-mouse immunoglobulins (conjugated with horseradish peroxidase, DakoCytomation, Glostrup, Denmark). Chemiluminescent detection was done using ECL Western blotting detection reagent (Amersham, Buckinghamshire, UK; Roleda et al. 2005). Developed films (using X-ray film developer) were scanned using Bio-Rad imaging densitometer (Model GS-700, Bio-Rad Laboratories, Hercules, CA, USA) and gray scale values were quantified using Multi-Analyst (Macintosh Software for BioRad's Image Analysis Systems). A calibration series of UV irradiated calf thymus DNA (Serva) supplemented with unexposed DNA was included giving $1 \mu \mathrm{g} \mathrm{ml}^{-1}$ DNA for each calibration point. The UV irradiated DNA (45 min exposure to 2 TL 20W/12 lamps, Philips, Eindhoven, The Netherlands) was previously calibrated against UV irradiated Hela DNA with known amounts of CPDs. CPDs were quantified by comparing the gray scales within the linear range of the film.

Data analysis

A one-way ANOVA was used to test for the effects of UVR on photosynthetic efficiency and DNA damage separately for each species and each exposure time $(P<0.05)$. Prior to analysis data were tested for homogeneity of variances (Cochran's test). Post-hoc comparisons were performed with Newman-Keuls test. Statistical analysis were done using Statistica ${ }^{\mathrm{TM}} 6.0$ software package.

\section{Results}

UV irradiance in the field and in the laboratory

Mean daily doses of UV-A and UV-B radiation in the field (air measurements from January to February 2005)

Table 2 Different treatments for the performed experiments including measured parameters (optimum quantum yield $=F_{\mathrm{v}} / F_{\mathrm{m}}$ and DNA damage $=$ CPDs)

\begin{tabular}{lllll}
\hline Species & Parameter & Treatment & Exposure & Recovery \\
\hline Monostroma hariotii & $F_{\mathrm{v}} / F_{\mathrm{m}}$ & PAB $+\mathrm{PA}+\mathrm{P}$ & $1,2,4,8 \mathrm{~h}$ & $48 \mathrm{~h}$ \\
& $\mathrm{CPDs}$ & $\mathrm{PAB}$ & $1,2,4,8 \mathrm{~h}$ & $48 \mathrm{~h}$ \\
Porphyra endiviifolium & $F_{\mathrm{v}} / F_{\mathrm{m}}$ & $\mathrm{PAB}+\mathrm{PA}+\mathrm{P}$ & $1,2,4,8 \mathrm{~h}$ & $48 \mathrm{~h}$ \\
& $\mathrm{CPDs}$ & $\mathrm{PAB}$ & $1,2,4,8 \mathrm{~h}$ & $48 \mathrm{~h}$ \\
Adenocystis utricularis & $F_{\mathrm{v}} / F_{\mathrm{m}}$ & $\mathrm{PAB}+\mathrm{PA}+\mathrm{P}$ & $1,2,4,8 \mathrm{~h}$ & $48 \mathrm{~h}$ \\
& $\mathrm{CPDs}$ & $\mathrm{PAB}$ & $1,2,4,8 \mathrm{~h}$ & $48 \mathrm{~h}$ \\
& $F_{\mathrm{v}} / F_{\mathrm{m}}$ & $\mathrm{PAB}+\mathrm{PA}+\mathrm{P}$ & $2,8,16 \mathrm{~h}$ & $24,48 \mathrm{~h}$ \\
& $F_{\mathrm{v}} / F_{\mathrm{m}}$ & PAB $+\mathrm{PA}+\mathrm{P}$ & $4 \mathrm{~h} /$ days over 5 days & $20 \mathrm{~h} /$ days over 5 days
\end{tabular}

Exposure and recovery time is the duration of the treatments PAB (PAR + UV-A + UV-B), PA (PAR + UV-A) and P (PAR) and recovery under dim white light, respectively. During recovery spores were exposed to a PAR of $4 \mu \mathrm{mol} \mathrm{m}^{-2} \mathrm{~s}^{-1}$ 
are shown in Table 3 in comparison to our treatments. Exposure to artificial UV-A radiation was lower in our experiments even after $16 \mathrm{~h}$ of irradiance than daily doses in the field. In contrast UV-B radiation in the $8 \mathrm{~h}$ treatment was similar to the daily doses measured in the field (Table 3).

\section{Photosynthesis: Irradiance curves}

The $P-I$ curves shown in Fig. $1 \mathrm{a}-\mathrm{c}$ reveal the differences in the photosynthetic performance of spores of the three species directly after spore release. The values for $\alpha$ (an index of light-harvesting system efficiency) varied between 0.065 and 0.139 (Fig. 1a-c). A similar steep slope was found in A. utricularis and $P$. endiviifolium, whereas $M$. hariotii showed the lowest $\alpha$ value. Highest saturating irradiance $\left(I_{\mathrm{k}}\right)$ was measured for reproductive cells of $M$. hariotii $(83 \mu \mathrm{mol}$ photons $\left.\mathrm{m}^{-2} \mathrm{~s}^{-1}\right)$, followed by A. utricularis $(64 \mu \mathrm{mol}$ photons $\left.\mathrm{m}^{-2} \mathrm{~s}^{-1}\right)$ and $P$. endiviifolium $\left(33 \mu \mathrm{mol}\right.$ photons $\mathrm{m}^{-2}$ $\mathrm{s}^{-1}$; Fig. 1a-c). At photon fluence rates $>300 \mu \mathrm{mol}$ photons $\mathrm{m}^{-2} \mathrm{~s}^{-1}, \quad \mathrm{rETR}_{\max }$ slightly decreased in A. utricularis and M. hariotii (Fig. 1a, b) whereas in P. endiviifolium $\mathrm{rETR}_{\max }$ decreased strongly after exceeding the actinic light level of $300 \mu \mathrm{mol}$ photons $\mathrm{m}^{-2} \mathrm{~s}^{-1}$. $\mathrm{rETR}_{\max }$ was higher in A. utricularis $\left(\mathrm{rETR}_{\max }=9\right)$ in comparison to $M$. hariotii $\left(\mathrm{rETR}_{\max }=5\right)$ and $P$. endiviifolium $\left(\mathrm{rETR}_{\max }=4\right)$.

Photosynthetic efficiency after short term exposure to $\mathrm{UV}$ radiation

Photosynthetic performance of the three species was affected differently by PAR, UV-A and UV-B radiation, respectively. Initial measurements of the controls showed that $P$. endiviifolium monospores had a slightly higher mean optimum quantum yield $\left(F_{\sqrt{ }} / F_{\mathrm{m}}=\right.$ $0.488 \pm 0.04)$ than $A$. utricularis spores $\left(F_{\mathrm{v}} / F_{\mathrm{m}}=0.462\right.$ $\pm 0.11)$ and both had a much higher optimum quantum yield compared with $M$. hariotii gametes $\left(F_{\sqrt{ }} / F_{\mathrm{m}}=\right.$

Table 3 UV-A and UV-B doses in the PAB (PAR + UVA + UV-B) treatment for different exposure times and in the field $(n=50)$ as means \pm SD of daily doses measured in January and February

\begin{tabular}{lcc}
\hline & $\mathrm{UV}-\mathrm{A}\left(\mathrm{kJ} \mathrm{m}^{-2}\right)$ & $\mathrm{UV}-\mathrm{B}\left(\mathrm{kJ} \mathrm{m}^{-2}\right)$ \\
\hline Laboratory & & \\
$1 \mathrm{~h}$ & 15.62 & 1.26 \\
$2 \mathrm{~h}$ & 31.25 & 2.52 \\
$4 \mathrm{~h}$ & 62.50 & 5.04 \\
$8 \mathrm{~h}$ & 124.99 & 10.08 \\
$16 \mathrm{~h}$ & 249.98 & 20.17 \\
Field daily & $318.06 \pm 122.39$ & $11.20 \pm 4.33$ \\
\hline
\end{tabular}

$0.288 \pm 0.04$, Fig. 2). The changes in optimum quantum yield during treatments are shown in Fig. 2. After $1 \mathrm{~h}$ treatment with PAR $\left(P ; 22 \mu\right.$ mol photons $\left.\mathrm{m}^{-2} \mathrm{~s}^{-1}\right)$ the optimum quantum yield $\left(F_{\mathrm{v}} / F_{\mathrm{m}}\right)$ was not affected in A. utricularis whereas in $M$. hariotii and $P$. endiviifolium it was already reduced to 62 and $81 \%$ (expressed as the percentage of control), respectively (Fig. 2a, c, e). Increasing exposure time did not further affect $F_{\mathrm{v}} / F_{\mathrm{m}}$ in $A$. utricularis which remained still high after $8 \mathrm{~h}$ exposure. In $M$. hariotii highest inhibition was found after $1 \mathrm{~h}$ and did not significantly change with further exposure. However, in P. endiviifolium increasing exposure time further decreased the $F_{\sqrt{ }} / F_{\mathrm{m}}$. PAR supplemented with UV-A (PA treatment) decreased photosynthetic efficiency significantly compared to the $P$ treatment in all three species during exposure. Two exceptions were the $8 \mathrm{~h}$ treatment of $M$. hariotii and $P$. endiviifolium where no significant UV effect compared to the $8 \mathrm{~h}$ exposure to higher PAR was detected. Additional UV-B (PAB treatment) generally did not reveal a further significant decrease of optimum quantum yield. Interestingly, $F_{\mathrm{v}} / F_{\mathrm{m}}$ of the PAB treatment in A. utricularis increased again after $8 \mathrm{~h}$ exposure (reduction after $1 \mathrm{~h}$ to $37 \%$, after $8 \mathrm{~h}$ to $57 \%$ of the control measurement). In all treatments photosynthetic efficiency was reduced by $55-82 \%$ due to UVR in comparison to the respective $P$ treatments.

However, all species showed a complete recovery of photosynthesis after 2 days under dim white light compared to the controls (ANOVA, $P>0.05$ ) and no differences between treatments were detected. In $A$. utricularis $F_{\sqrt{ }} / F_{\mathrm{m}}$ increased in the controls from $0.462 \pm 0.114$ before treatment to $0.601 \pm 0.044$ (mean $\pm \mathrm{SD}$ ) after 2 days recovery and in $M$. hariotii from $0.288 \pm 0.040$ to $0.400 \pm 0.149$ (mean $\pm \mathrm{SD}$ ), respectively. However, in $P$. endiviifolium $F_{\sqrt{ }} / F_{\mathrm{m}}$ decreased in the controls from $0.488 \pm 0.040$ at the beginning of the experiment to $0.249 \pm 0.023$ (mean $\pm \mathrm{SD}$ ) after 2 days (Fig. 2a-f).

A second experiment with $A$. utricularis conducted with a longer exposure time (see also light doses in Table 3) and recovery measured after 24 and $48 \mathrm{~h}$ followed the same pattern as described above. UVR significantly reduced optimum quantum yield of spores in comparison to the $P$ treatment (Fig. 3). After 8 and $16 \mathrm{~h}$ additional UV-B radiation reduced $F_{\mathrm{v}} / F_{\mathrm{m}}$ significantly more than UV-A alone (Newman-Keuls, $P<0.05$ between PAB and PA). An incomplete recovery occurred after $24 \mathrm{~h}$ in the $16 \mathrm{~h}$ exposure treatments of PA and PAB (ANOVA, $F_{2,12}=15.03, P=0.0005$ ). However, all samples recovered in all treatments after $48 \mathrm{~h}$ (Fig. 3). 
Fig. 1 Photosynthetic performance $(P-I$ curves, $n=3)$ of spores of Adenocystis utricularis (a), Monostroma hariotii (b) and Porphyra endiviifolium (c) after spore release. PFR is the respective photon fluence rate of actinic white light and rETR is the relative electron transport rate (a)
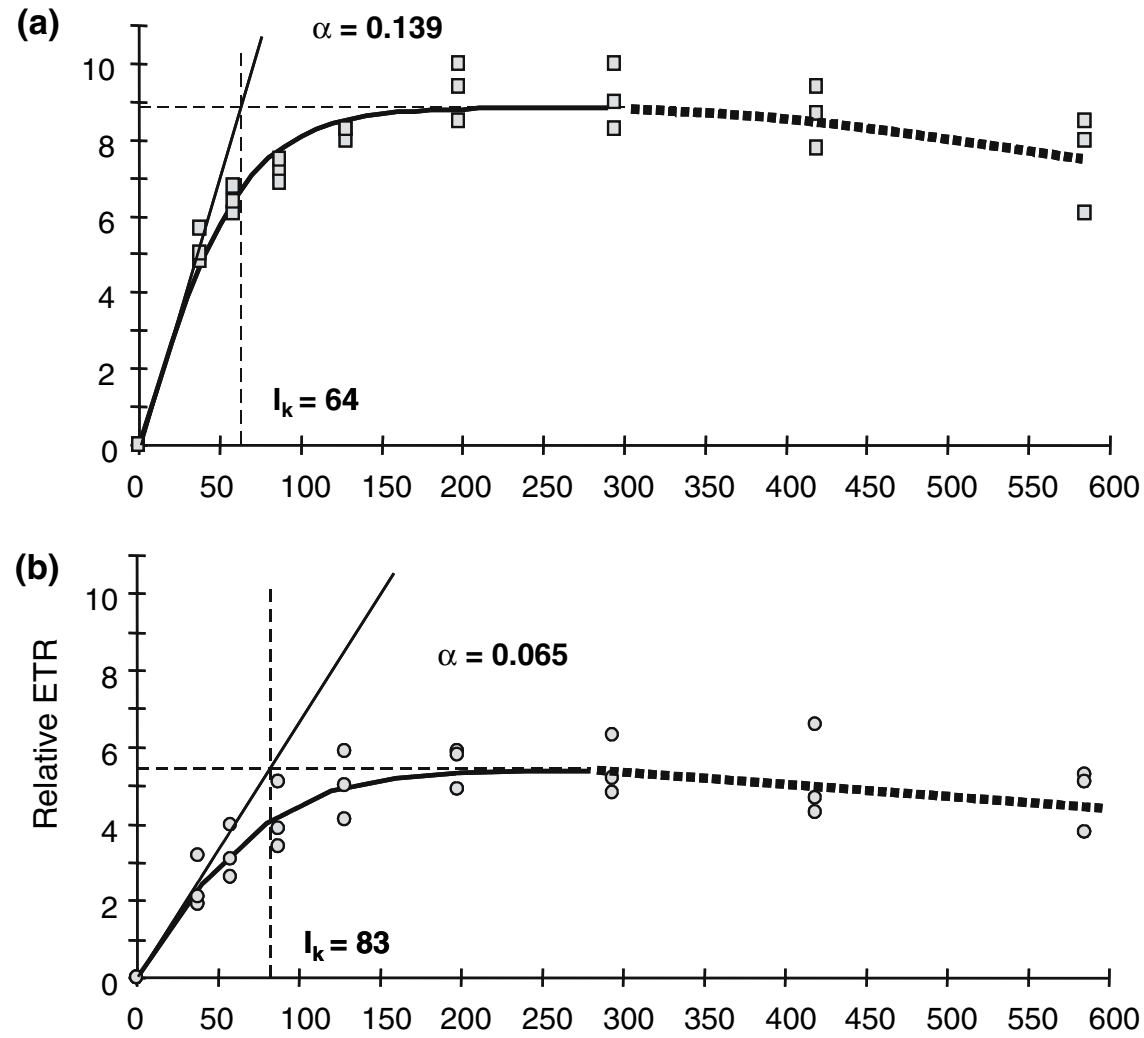

(c)

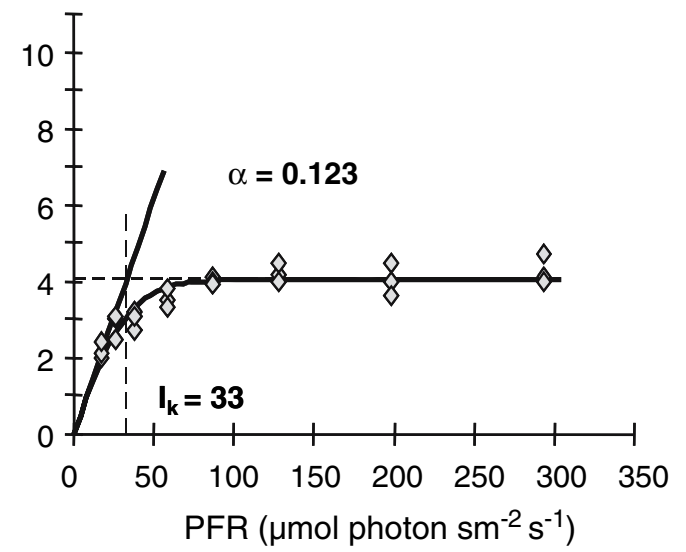

Time series of repeated UVR irradiance on A. utricularis spores

Repeated measurements of the same samples did not significantly affect the optimum quantum yields, as shown with the comparison of undisturbed control and disturbed control (measured at the beginning and the end of the experiment, Table 4, $P>0.005$ ).

The time series measurements over a 5 days period did not show significant differences between the optimum quantum yield of the controls (maintained under $4 \mu \mathrm{mol}$ photons $\mathrm{m}^{-2} \mathrm{~s}^{-1}$ ) and the $P$ treatments under higher PAR $\left(22 \mu \mathrm{mol}\right.$ photons $\left.\mathrm{m}^{-2} \mathrm{~s}^{-1}, P>0.05\right)$. However, additional UV-A and the combination from UV-
A and UV-B radiation led to a significant decrease in $F_{\sqrt{ }} / F_{\mathrm{m}}$ after each of the $4 \mathrm{~h}$ treatments (Fig. 4). The decrease over time in the PA treatment did not significantly change (ANOVA, $F_{4,20}=0.91, P=0.477$ ) during the 5 days and ranged from 48 to $56 \%$. On the other hand, the effects of the PAB treatment changed over time (ANOVA, $\left.F_{4,20}=5.36, P=0.004\right)$. After a significant increase in $F_{\sqrt{ }} / F_{\mathrm{m}}$ from days 1 to 2 (NewmanKeuls, $P=0.020), F_{\mathrm{v}} / F_{\mathrm{m}}$ dropped significantly from days 2 to 5 (Newman-Keuls, $P=0.003$ ) after $4 \mathrm{~h}$ exposure. Optimum quantum yield was reduced to $41 \%$ (on day 2 ) and to $28 \%$ (on day 5 ) in comparison to the control.

A complete recovery was measured after $20 \mathrm{~h}$ under dim white light with one exception on day 4 (PAB sig- 

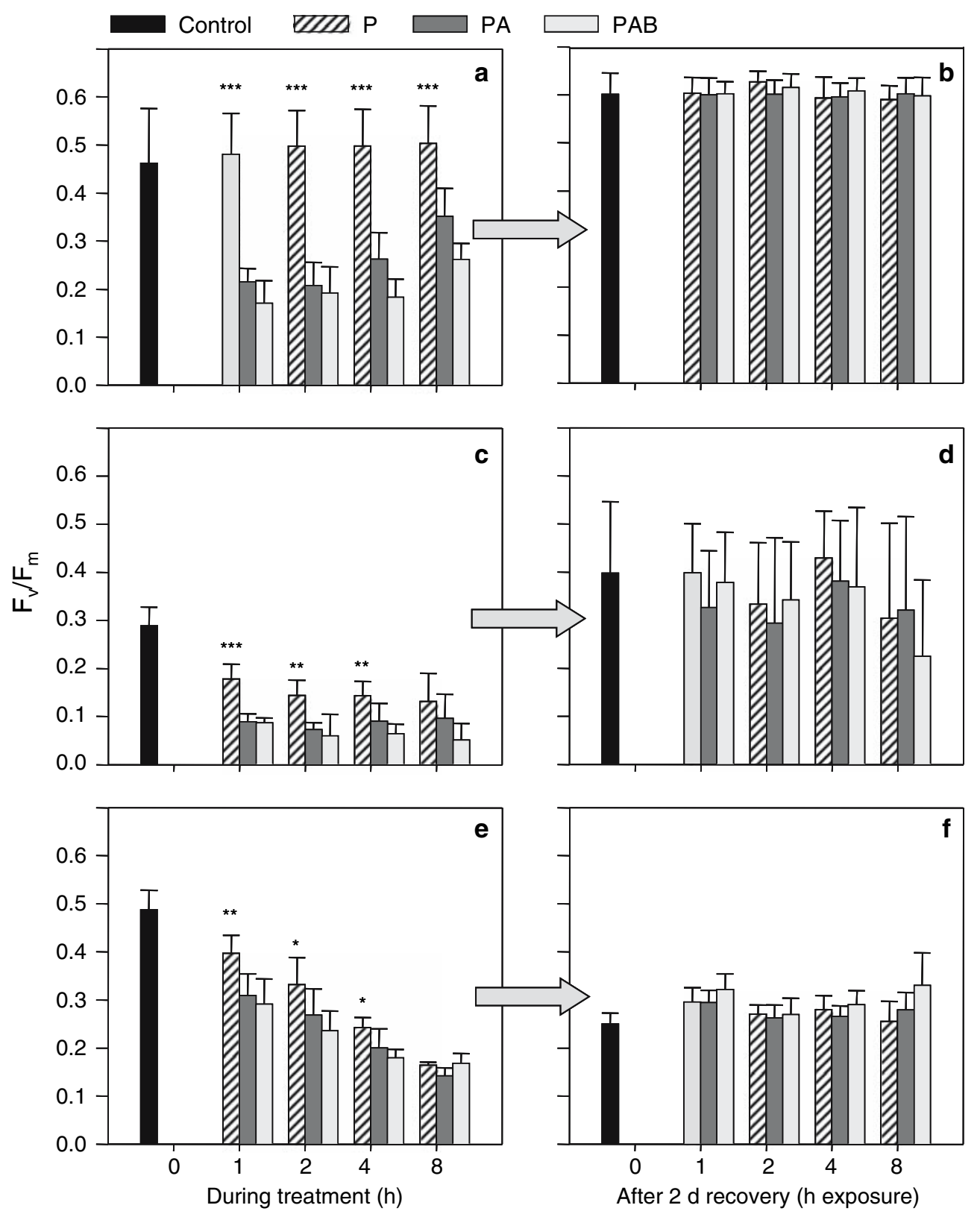

Fig. 2 Mean optimum quantum yield $\left(F_{\mathrm{v}} / F_{\mathrm{m}}\right) \pm \mathrm{SD}(n=5)$ of reproductive cells of Adenocystis utricularis $(\mathbf{a}, \mathbf{b})$ Monostroma hariotii (c, d) and Porphyra endiviifolium (e, f) after exposure to PAR (P), PAR + UV-A (PA) and PAR + UV-A + UV-B (PAB) and after 2 days of recovery, respectively. Control (C) is without treatment and continuously maintained under $4 \mu \mathrm{mol}$ photons $\mathrm{m}^{-2} \mathrm{~s}^{-1}$ white light. Asterisks indicate significant differences between the $P$ and PA and/or PAB treatment. Significance levels were defined as follows: $* * * P<0.001, \quad * * P=0.001-0.01$, $* P=0.01-0.05$ nificantly different from $P$, ANOVA, $F_{2,12}=5.00$, $P=0.026$; Fig. 4).

DNA damage and repair

No detectable DNA damage (measured as CPD concentrations per million nucleotides, $\mathrm{CPD} \mathrm{Mbp}^{-1}$ ) was found in $P$. endiviifolium monospores and only minimal
DNA damage in propagules of $A$. utricularis (2, 4, and $8 \mathrm{~h}$ treatment) and $M$. hariotii (4 and $8 \mathrm{~h}$ treatment; Fig. 5) after exposure to PAB. CPD induction significantly increased in both species from 2 (4) to $8 \mathrm{~h} \mathrm{PAB}$ exposure time (ANOVA, $F_{1,6}=11.95, P=0.008$ and $F_{1}$, ${ }_{4}=7.85, P=0.049$ for $A$. utricularis and $M$. hariotii, respectively). After 2 days recovery under dim white light all species were able to repair the DNA damage. 

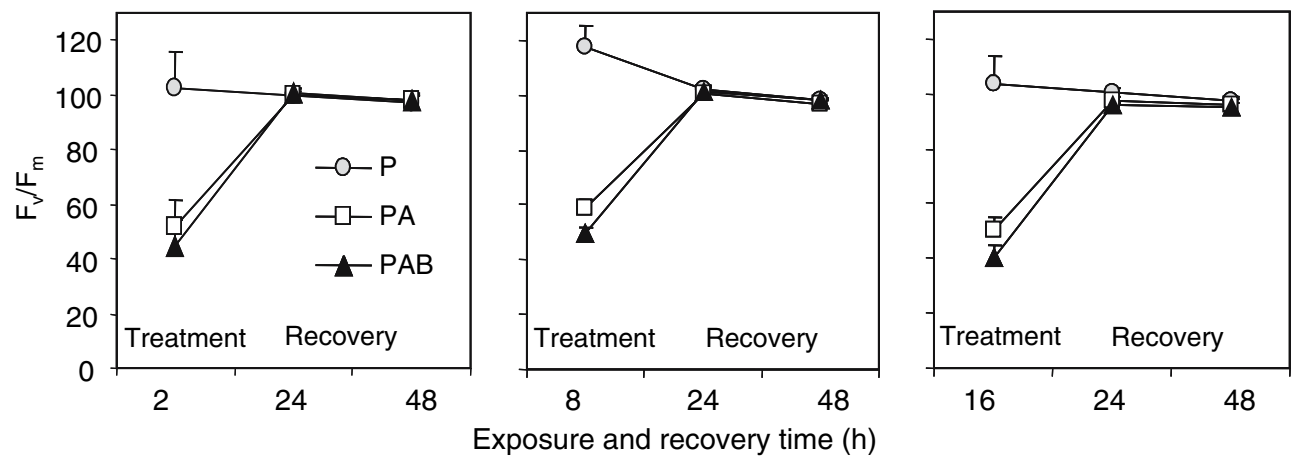

Fig. 3 Mean optimum quantum yield $\left(F_{\mathrm{v}} / F_{\mathrm{m}}\right) \pm \mathrm{SD}(n=5)$ expressed as percentage of the respective control of Adenocystis utricularis spores after exposure (treatment 2, 8, and $16 \mathrm{~h}$ ) to PAR $(P)$, PAR + UV-A $(P A)$ and PAR + UV-A + UV-B $(P A B)$

Table 4 Mean optimum quantum yield $\left(F_{\mathrm{v}} / F_{\mathrm{m}} \pm \mathrm{SD}\right)$ of untreated zoospores of Adenocystis utricularis (controls) after release and at different time series intervals (see Fig. 4 for treatment effects)

\begin{tabular}{llll}
\hline Day & Hours & $\begin{array}{l}\text { Disturbed } \\
\text { control }\end{array}$ & $\begin{array}{l}\text { Undisturbed } \\
\text { control }\end{array}$ \\
\hline 0 initial & 0 & $0.579 \pm 0.031$ & $0.571 \pm 0.028$ \\
1 & 4 & $0.598 \pm 0.020$ & - \\
& 24 & $0.642 \pm 0.014$ & - \\
2 & 28 & $0.631 \pm 0.012$ & - \\
& 48 & $0.643 \pm 0.011$ & - \\
3 & 52 & $0.640 \pm 0.012$ & - \\
& 72 & $0.649 \pm 0.006$ & - \\
4 & 76 & $0.652 \pm 0.005$ & - \\
& 96 & $0.658 \pm 0.007$ & - \\
5 & 100 & $0.653 \pm 0.007$ & - \\
& 120 & $0.665 \pm 0.007$ & $0.669 \pm 0.005$ \\
\hline
\end{tabular}

Disturbed control is without treatment, continuously maintained under $4 \mu \mathrm{mol}$ photons $\mathrm{m}^{-2} \mathrm{~s}^{-1}$ white light and measured at the same time intervals as the treated samples. Undisturbed control was measured once before the start and at the end of the experiment to determine weather samples get disturbed due to the measurements. In the meantime it was continuously maintained under $4 \mu \mathrm{mol}$ photons $\mathrm{m}^{-2} \mathrm{~s}^{-1}$

\section{Discussion}

Our experiments showed that propagules from the Antarctic intertidal are well fitted to survive in their extreme habitat, although this life stage is the most susceptible to environmental stress factors. This study is among the first testing UVR effects on intertidal propagules of seaweeds and the first with Antarctic species.

In the laboratory experiments a UV-A:UV-B ratio of $12: 1$ is emitted by the lamps, whereas in the field the proportion of UV-A is more than two times higher. Even stronger is the difference in the ratio between PAR:UV-A:UV-B which was 790:19:1 $(n=112)$ in the field in air (data not shown) and only 13.5:12.4:1 in and after 24 and $48 \mathrm{~h}$ of recovery, respectively. $F_{\mathrm{v}} / F_{\mathrm{m}}$ of controls were $0.4574 \pm 0.0541$ (treatment) $0.6072 \pm 0.0209$ (24-h recovery) and $0.6408 \pm 0.0113$ (48-h recovery), respectively

the laboratory. The lower doses in the laboratory in relation to field air measurements were chosen to take the absorption by the water column into account. For example only $55 \%$ of UV-A and $60 \%$ of UV-B radiation reached the sample area in $10 \mathrm{~cm}$ water depth. Therefore, the 8-h treatment reflects the most natural situation in terms of daily UV doses for $A$. utricularis and $M$. hariotii whereas $P$. endiviifolium is exposed to higher doses due to its occurrence at the high tide level. However, maximal irradiances and doses in the intertidal are generally highly variable, depending, e.g., on tide level, water turbidity and weather conditions.

The $I_{\mathrm{k}}$ of $P$. endiviifolium is much lower than the $I_{k}$ values of $A$. utricularis and $M$. hariotii. Low light adapted macroalgae have a saturation point ranging between 14 and $52 \mu \mathrm{mol} \mathrm{m}^{2-} \mathrm{s}^{-1}$ (Hanelt et al. 2003) characterizing spores of $P$. endiviifolium as strongly shade adapted. In contrast propagules of $A$. utricularis and $M$. hariotii seem to be less strongly shade adapted.

These results are in agreement with measured $I_{\mathrm{k}}$ values for the adult thalli. Weykam et al. (1996) showed that the $I_{\mathrm{k}}$ values of adult Antarctic Rhodophyta are low compared to Chlorophyta or Phaeophyta. Results on zoospores of Arctic Laminariales generally showed a high shade adaption ( $I_{\mathrm{k}}$ between 13 and $18 \mu \mathrm{mol} \mathrm{m}^{-2} \mathrm{~s}^{-1}$, Roleda et al. 2006a). In contrast, $I_{\mathrm{k}}$ values of zoospores of cold temperate Laminaria species range between 20 and $40 \mu \mathrm{mol} \mathrm{m}{ }^{-2} \mathrm{~s}^{-1}$ (Roleda et al. 2005) while kelp zoospores from the warm temperate regions have higher $I_{\mathrm{k}}$ ranging from 41 to $77 \mu \mathrm{mol} \mathrm{m}^{-2} \mathrm{~s}^{-1}$ (Amsler and Neushul 1991). The geographical trend with low values in the polar and higher ones in warmer regions corresponding to the increasing solar irradiance from the poles to the equator (Roleda et al. 2006a) could not be confirmed for Antarctic propagules with saturating irradiances within the range of temperate species. However, $I_{\mathrm{k}}$ values are also 
Fig. 4 Time series of repeated UV irradiation on spores of Adenocystis utricularis. Mean optimum quantum yield $\left(F_{\mathrm{v}}\right.$ $\left.F_{\mathrm{m}}\right) \pm 1 \mathrm{SD}(n=5)$ of spores after $4 \mathrm{~h}$ exposure ( $\mathrm{t} 1$ to $\mathrm{t} 5)$ to PAR $(P)$, PAR +UV-A $(P A)$ and $\mathrm{PAR}+\mathrm{UV}-$ $\mathrm{A}+\mathrm{UV}-\mathrm{B}(P A B)$ and after subsequent $20 \mathrm{~h}$ of recovery (rec 1-5) repeated over 5 days, respectively. Different letters indicate significant differences between the treatments

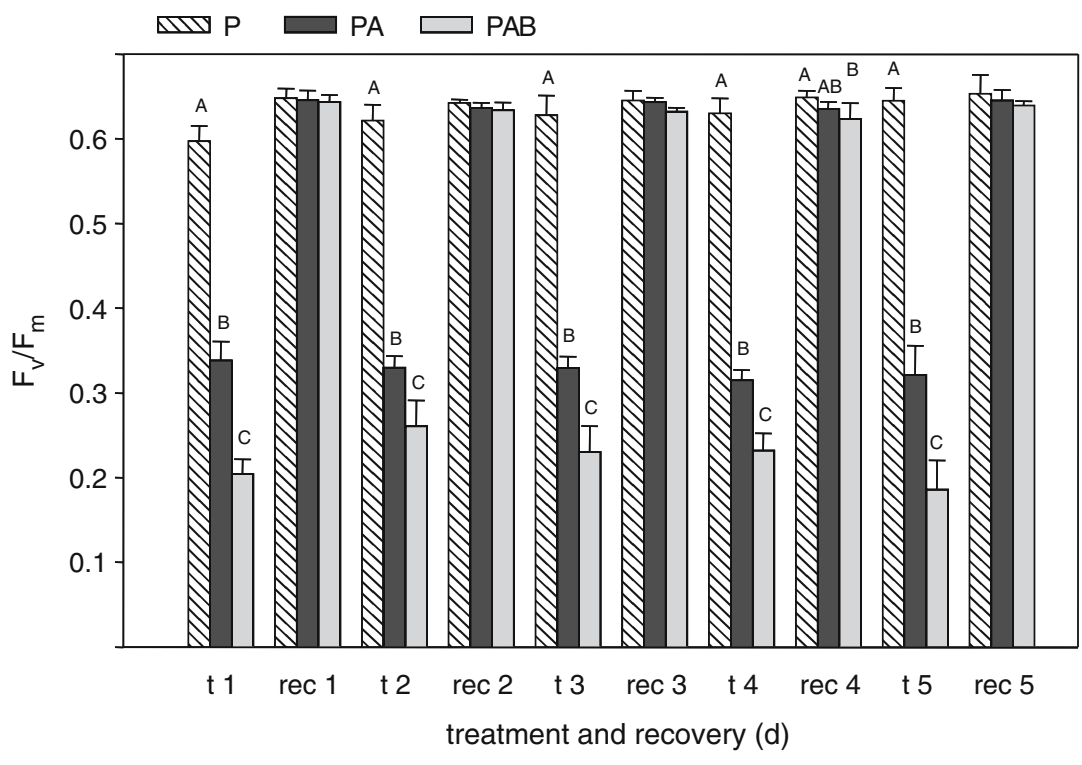

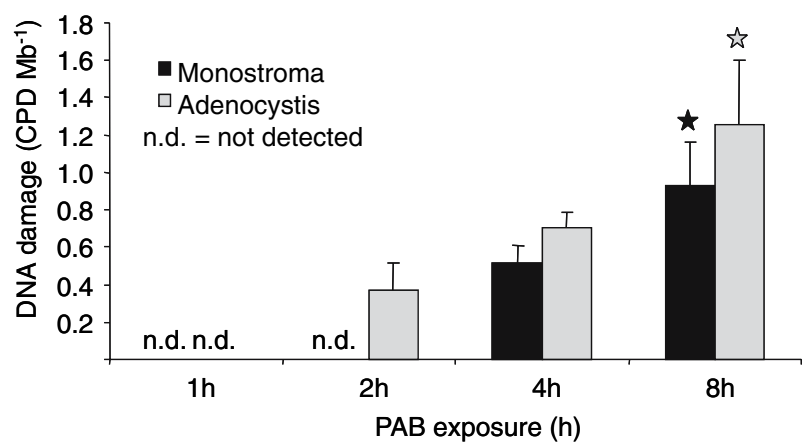

Fig. 5 UV-B induced DNA damage (mean $\pm \mathrm{SD}, n=3$, induced CPD concentrations per million nucleotides) in Adenocystis utricularis spores and Monostroma hariotii gametes after exposure to different doses of PAB (PAR + UV-A + UV-B, 1, 2, 4, and $8 \mathrm{~h}$ ). CPDs were not detected in Porphyra endiviifolium and in all species after 2 days recovery under dim white light $(4 \mu \mathrm{mol}$ photons $\mathrm{m}^{-2} \mathrm{~s}^{-1}$ ) no more CPDs were detected. Significant differences among the different exposure times for each species are marked with asterisk

dependent on algal zonation on the shore with higher values measured for macroalgae from shallower water depth (Roleda et al. 2006a). In our study only intertidal species were tested explaining the relatively high $I_{\mathrm{k}}$ values. $\mathrm{rETR}_{\max }$ was not inhibited by actinic light $<300 \mu \mathrm{mol} \mathrm{m} \mathrm{m}^{-2} \mathrm{~s}^{-1}$ showing good adaptations to higher PAR levels according to the occurrence of the adult thalli in the upper eulittoral. Eulittoral algae are periodically exposed to air where they experience a variety of stressful environmental conditions, e.g., very high light intensities (Davison and Pearson 1996). The potential for acclimation and recovery of the photosynthetic apparatus to high or damaging radiation conditions is therefore an important pre-requisite for the recruitment and ecological success of algae growing in the intertidal (Roleda et al. 2006a).

In general, photosynthetic efficiency $\left(F_{\sqrt{ }} / F_{\mathrm{m}}\right)$ of freshly released propagules was lower compared to young or adult macrothalli as also shown in other studies (Wiencke et al. 2000; Roleda et al. 2004b). This can be attributed to the development stage of the chloroplast in different life stages. Laminariales zoospores with thin plasmalemma and one chloroplast per cell, e.g., are more sensitive to light stress (Roleda et al. 2006a). In contrast to the other two species optimum quantum yield of Porphyra spores decreased during the experiment in the controls maybe due to non-optimal cultivation conditions for this species.

Reaction to $\mathrm{P}, \mathrm{PA}$ and $\mathrm{PAB}$ exposure in propagules was species-specific, indicating a higher light sensitivity of the green algae $M$. hariotii and the red algae $P$. endiviifolium. High light conditions during e.g., low tide or high water transparency might therefore influence their propagules survival more negatively than in $A$. utricularis. However, the reaction of propagules to high light stress remains to be tested.

Reduction of photosynthetic efficiency while exposed to high PAR is a protective mechanism to dissipate energy absorbed by PSII as heat via the xanthophylls cycle to avoid photodamage (dynamic photoinhibition; Osmond 1994). UVR exhibited an additional effect in the reduction of $F_{\mathrm{v}} / F_{\mathrm{m}}$ in all species. The measurable effects of both PAR and UVR in the reduction of photosynthetic efficiency are similar but the mechanisms behind PAR and UVR induced inhibition of photosynthesis are different (Hanelt et al. 2003). UVR exhibits adverse effects on photosynthesis causing a direct molecular damage due to the absorp- 
tion by biomolecules (Vass 1997). Depression of photosynthetic performance by UVR is, e.g., implicated to the damage of the oxidizing site of the reaction center of photosystem II (Franklin et al. 2003).

In contrast to eulittoral $A$. utricularis, spores of sublittoral Arctic Laminariales reacted already with a strong depression of $F_{\sqrt{ }} / F_{\mathrm{m}}$ under PAR of $22 \mu \mathrm{mol}$ photon $\mathrm{m}^{-2} \mathrm{~s}^{-1}$ (Roleda et al. 2006a). Furthermore Laminariales zoospores from Helgoland (Germany) were not able to recover after $8 \mathrm{~h}$ exposure to $\mathrm{PAB}$ in a comparable experiment (Roleda et al. 2005) indicating that the Antarctic intertidal Adenocystis is better acclimated to PAR and UVR. Results from irradiance experiments with intertidal carpospores from the red algae Chondrus crispus and Mastocarpus stellatus from the North Sea (Helgoland, Germany) showed that spores of these species react more sensitive to PAR and UVR than $P$. endiviifolium monospores (Roleda et al. 2004b). This difference is surprising as at least $M$. stellatus is able to grow in the upper eulittoral zone as well (Roleda et al. 2004b).

The monostromatic thallus of Monostroma arcticum from the Arctic is, in comparison to other investigated Arctic Chlorophyta and eulittoral Phaeophyta quite light sensitive, fast photoinhibited but recovering slowly, an indication of chronic photoinhibiton (Hanelt 1998). The monospores from $M$. hariotii exibit a similar behavior, as they were more light sensitive than the brown alga $A$. utricularis, but less sensitive than the red alga $P$. endiviifolium.

Short time experiments (8-h exposure) gave evidence of a possible acclimation of the photosynthetic apparatus of $A$. utricularis to UV-A and UV-B radiation as found in other studies with brown algae (Bischof et al. 1999; Roleda et al. 2004a). However, no such effect was observed after exposure to $16 \mathrm{~h}$ and after repeated exposure over a period of 5 days. In contrast to the earlier experiments additional UV-B significantly decreased photosynthetic efficiency further and inhibition was highest after 5 days suggesting a higher degree of damage due to repeated exposures. Apparently spores of $A$. utricularis lack acclimation abilities and are not able to diminish the inhibition caused by repeated UV exposure. After $20 \mathrm{~h}$ under dim white light, however, $F_{\mathrm{v}} / F_{\mathrm{m}}$ recovered completely.

The non-detectable DNA damage in $P$. endiviifolium spores and minimal CPD formation in A. utricularis and $M$. hariotii propagules indicate effective shielding of the DNA and/or fast repair mechanism in the Antarctic intertidal propagules. The degree of damage due to UVR was observed to be related to cell size as DNA damage was observed to decrease in species (Adenocystis, Monostroma, Porphyra) with increasing cell size $(4,7$, and $15 \mu \mathrm{m}$, respectively). This might be attributed to the increasing pathway for UVB penetration through the cytoplasm (filtering effect; Swanson and Druehl 2000). In other studies, UV induced damage was related to thallus thickness (Franklin and Forster 1997; Johansson and Snoeijs 2002), e.g., thinner and relatively translucent species showed more DNA damage than thicker ones. An effective DNA repair mechanism was also observed in spores of Arctic and temperate Laminariales and Gigartinales but initial CPD formation was much higher (Roleda et al. 2004b, 2005).

DNA damage can be repaired through photolyase enzyme (light-dependent), nucleotide excision and recombination repair (light-independent; van de Poll et al. 2002). M. arcticum from Spitsbergen was not able to repair UV-B induced CPD formation probably due to low photolyase activity which has an important role in removing the majority of CPDs (van de Poll et al. 2002). The small amount of DNA damage in the tested Antarctic species might therefore be related to high photolyase activity. Another possibility is shielding due to UV absorbing compounds. However, whether the tested propagules are able to produce some kind of UV protective substance or have a high photolyase activity remains to be studied. Anyway, the ability of the propagules to cope with UV-B induced DNA damage seems to be crucial for the vertical zonation of the macrothalli at the coastline. If not repaired, DNA lesions can disrupt metabolism, cell division and impair growth and germination. Most macroalgae in Antarctica occur only in the subtidal (Wiencke et al. 2006a) and few are able to recruit in the intertidal partly due to their capacity to successfully repair DNA damage.

In general, exposure to the UV doses used in our laboratory experiment should not affect the survival and success of the investigated intertidal algae on short term view as all species recovered effectively from UV induced damage. However, in the field, maximal light intensities can be much higher especially when low tide coincides with noon and cloudless weather conditions. Longer exposure to ambient radiation over more than $8 \mathrm{~h}$ can take place and PAR would be much higher when cells are suspended within the euphotic layer of the water column. Therefore, field experiments on propagules are of great importance also taking into account parameters like germination and growth as integrative parameters of all physiological processes. Nevertheless, laboratory experiments give valuable insights in physiological mechanisms and common adaptations. Another important point is that these experiments were performed with field grown material as Swanson and Druehl (2000) hypothesized that kelp 
spores might be pre-adapted to the UV conditions of their parent plants. If so, experiments with cultured material would not reflect the actual situation in the field and might overestimate UV effects because culturing usually takes place under PAR light only. Generally, the propagules studied here seem to be better adapted to UVR than temperate or Arctic ones. On the other hand, most previous studies were performed with subtidal species, mostly Laminariales which makes a direct comparison difficult. More comparative studies on related species and their reproductive cells respectively, from different geographical regions but similar zonation would improve our knowledge about the species-specific reactions and adaptations to (elevated) UVR.

Acknowledgments The authors thank the dive team for collecting the samples. Thanks to A. Vink for providing Hela DNA. This work has been done under the agreement on scientific cooperation between the AWI and DNA at Dallmann Laboratory, annex to Jubany station, King Georg Island, Antarctica. Thanks to the Jubany and Dallmann team for their support. We gratefully acknowledge financial support by the German Research Council (DFG) and the Alfred Wegener Institute for Polar and Marine Research, Germany.

\section{References}

Amsler CD, Neushul M (1991) Photosynthetic physiology and chemical composition of spores of the kelps Macrocystis pyrifera, Nereocystis luetkeana, Laminaria farlowii, and Pterygophora californica (Phaeophyceae). J Phycol 27:26-34

Bischof K, Hanelt D, Tüg H, Karsten U, Brouwer PEM, Wiencke C (1998) Acclimation of brown algal photosynthesis to ultraviolet radiation in Arctic coastal water (Spitsbergen, Norway). Polar Biol 20:388-395

Bischof K, Hanelt D, Wiencke C (1999) Acclimation of maximal quantum yield of photosynthesis in the brown alga Alaria esculenta under high light and UV radiation. Plant Biol 1:435-444

Bischof K, Gomez I, Molis M, Hanelt D, Karsten U, Lüder U, Roleda MY, Zacher K, Wiencke C (2006) Ultraviolet radiation shapes seaweed communities. Rev Environ Sci Biotechnol, DOI 10.1007/s11157-006-0002-3

Coelho SM, Rijstenbil JW, Brown MT (2000) Impacts of anthropogenic stresses on the early development stages of seaweeds. J Aquat Ecosystem Stress Recov 7:317-333

Davison IR, Pearson GA (1996) Stress tolerance in intertidal seaweeds. J Phycol 32:197-211

Dobretsov SV, Qian P-Y, Wahl M (2005) Effects of solar ultraviolet radiation on the formation of shallow, early successional biofouling communities in Hong Kong. Mar Ecol Prog Ser 290:55-65

Franklin LA, Forster RM (1997) Review: the changing irradiance environment: consequences for marine macrophyte physiology, productivity and ecology. Eur J Phycol 32:207-232

Franklin LA, Osmond CB, Larkum AWD (2003) Photoinhibition, UV-B and algal photosynthesis. In: Larkum AW, Douglas SE, Raven JA (eds) Photosynthesis in algae. Kluwer Academic Publishers, The Netherlands, pp 351-384
Hanelt D (1996) Photoinhibition of photosynthesis in marine macroalgae. Sci Mar 60:343-348

Hanelt D, Wiencke C, Nultsch W (1997) Influence of UV radiation on the photosynthesis of Arctic macroalgae in the field. J Photochem Photobiol B Biol 38:40-47

Hanelt D (1998) Capability of dynamic photoinhibition in Arctic macroalgae is related to their depth distribution. Mar Biol 131:361-369

Hanelt D, Wiencke C, Bischof K (2003) Photosynthesis in Marine Macroalgae. In: Larkum AW, Douglas SE, Raven JA (eds) Photosynthesis in algae. Kluwer Academic Publishers, The Netherlands, pp 412-435

Hanken T, Tüg H (2002) Development of a multichannel UVspectroradiometer for field measurements. Environ Sci Pollut Res Int 4:35-39

Jassby AD, Platt T (1976) Mathematical formulation of the relationship between photosynthesis and light for phytoplankton. Limnol Oceanogr 21:540-547

Johansson G, Snoeijs P (2002) Macroalgal photosynthetic responses to light in relation to thallus morphology and depth zonation. Mar Ecol Prog Ser 244:63-72

Lao ML, Glazer AN (1996) Ultraviolet-B photodestruction of a light-harvesting complex. Proc Natl Acad Sci USA 93:52585263

Larkum AWD, Wood WF (1993) The effect of UV-B radiation on photosynthesis and respiration of phytoplankton, benthic macroalgae and seagrass. Photosynth Res 36:17-23

Mann KH (1973) Seaweeds: their productivity and strategy for growth. Science 182:975-981

Osmond CB (1994) What is photoinhibition? Some insights from comparisons of shade and sun plant. In: Baker NR, Bowyer JR (eds) Photoinhibition of photosynthesis, from the molecular mechanisms to the field. BIOS Scientific Publications, Oxford, pp 1-24

Reed DC, Laur DR, Ebeling AW (1988) Variation in algal dispersal and recruitment: the importance of episodic events. Ecol Monogr 58:321-335

Rijstenbil JW, Coelho SM, Eijsackers M (2000) A method for the assessment of light-induced oxidative stress in embryos of fucoid algae via confocal laserscan microscopy. Mar Biol 137:763-774

Roleda MY, Hanelt D, Kräbs G, Wiencke C (2004a) Morphology, growth, photosynthesis and pigments in Laminaria ochroleuca (Laminariales, Phaeophyta) under ultraviolet radiation. Phycologia 43:603-613

Roleda MY, van de Poll WH, Hanelt D, Wiencke C (2004b) PAR and UVBR effects on photosynthesis, viability, growth and DNA in different life stages of two coexisting Gigartinales: implications for recruitment and zonation patterns. Mar Ecol Prog Ser 281:37-50

Roleda MY, Wiencke C, Hanelt D, van de Poll WH, Gruber A (2005) Sensitivity of Laminariales zoospores from Helgoland (North Sea) to ultraviolet and photosynthetically active radiation; implications for depth distribution and seasonal reproduction. Plant Cell Environ 28:466-479

Roleda MY, Hanelt D, Wiencke C (2006a) Exposure to ultraviolet radiation delays photosynthetic recovery in Arctic kelp zoospores. Photosynth Res DOI 10.1007/s11120-006-9055-y

Roleda MY, Hanelt D, Wiencke C (2006b) Growth and DNA damage in young Laminaria sporophytes exposed to ultraviolet radiation: implication for depth zonation of kelps on Helgoland (North Sea). Mar Biol 148:1201-1211

Swanson AK, Druehl LD (2000) Differantial meiospore size and tolerance of ultraviolet light stress within and among kelp species along a depth gradient. Mar Biol 136:657-664 
Vadas RL Sr, Johnson S, Norton TA (1992) Recruitment and mortality of early post-settlement stages of benthic algae. Brit Phycol J 27:331-351

van de Poll WH, Eggert A, Buma AGJ, Breemann AM (2001) Effects of UV-B-induced DNA damage and photoinhibition on growth of temperate marine red macrophytes: habitat-related differences in UV-B tolerance. J Phycol 37:30-37

van de Poll WH, Hanelt D, Hoyer K, Buma AGJ, Breemann AM (2002) Ultraviolet-B induced cyclobutane-pyrimidine dimer formation and repair in Arctic marine macrophytes. Photochem Photobiol 76:493-501

Vass I (1997) Adverse effects of UV-B light on the structure and function of the photosynthetic apparatus. In: Pessarakli M (ed) Handbook of photosynthesis. Marcel Dekker Inc., New York, pp 931-949

Weykam G, Gómez I, Wiencke C, Iken K, Klöser H (1996) Photosynthetic characteristics and $\mathrm{C}: \mathrm{N}$ ratios of macroalgae from King George Island (Antarctica). J Exp Mar Biol Ecol 204:1-22
Wiencke C, Gómez I, Pakker H, Flores-Moya A, Altamirano M, Hanelt D, Bischof K, Figueroa FL (2000) Impact of UV-radiation on viability, photosynthetic characteristics and DNA of brown algal zoospores: implications for depth zonation. Mar Ecol Prog Ser 197:217-229

Wiencke C, Clayton MN, Gómez I, Iken K, Lüder UH, Amsler CD, Karsten U, Hanelt D, Bischof K, Dunton K (2006a) Life strategy, ecophysiology and ecology of seaweeds in polar waters. Rev Environ Sci Biotechnol, DOI 10.1007/s11157-0060001-4

Wiencke C, Roleda MY, Gruber A, Clayton MN, Bischof K (2006b) Susceptibility of zoospores to UV radiation determines upper depth distribution limit of Arctic kelps: evidence through field experiments. J Ecol 94:455-463

WMO (World Meteorological Organization) (2003) Scientific assessment of ozone depletion (2002) Global ozone research and monitoring project-Report No. 47, Geneva 